\title{
Elementos do processo de execução fiscal
}

Leonardo Rizo Salomão ${ }^{1}$

\section{Resumo}

\begin{abstract}
Seguramente, o executivo fiscal é um dos processos de maior incidência no foro, seja federal ou estadual. Por isso, compreendê-lo é tarefa obrigatória para todos os cientistas do direito, especialmente, os que se voltam ao estudo do direito público. $\mathrm{E}$, neste artigo, o Autor realiza um estudo do processo de execução fiscal na perspectiva da teoria geral do processo. Analisa algumas questões teóricas referentes à Jurisdição, à Execução e ao Processo para, ao final, sintetizar as informações obtidas no que denomina por elementos do processo de execução fiscal.
\end{abstract}

Palavras-Chave: Inafastabilidade da jurisdição; Direito de ação; Execução fiscal; Dívida ativa; Título executivo; Processo de execução fiscal; Atos executivos.

\section{Introdução}

Seguramente, o executivo fiscal é um dos processo de maior incidência no foro, seja federal ou estadual, por isso, compreendê-lo é tarefa obrigatória para todos os cientistas do direito, especialmente, os que se voltam ao estudo do direito público.

O processo de execução fiscal representa uma garantia fundamental pela qual o devedor somente será despojado do seu patrimônio na exata proporção do seu débito e pelo meio menos gravoso aos seus direitos. É um desdobramento da garantia ao devido processo legal, do princípio da legalidade e do direito à propriedade (mas não somente!). Sua magnitude está em constituir-se num instrumento ético para a solução dos conflitos entre o Executado e a Fazenda Pública Exequente a partir de regras previamente estabelecidas perante um Órgão Constitucional investido na função jurisdicional com independência e imparcialidade.

Com efeito, compreender o Executivo Fiscal à luz da teoria geral do processo é o objeto deste artigo. A intenção é cotejar algumas bases teóricas que tratam da Jurisdição, da

1 O Autor é professor de Direito Administrativo no curso de Gestão pública e planejamento urbano da Universidade do Oeste Paulista (UNOESTE) em Presidente Prudente - SP. Pós-Graduando pela Universidade Estadual em Londrina (UEL) no Curso de Especialização em Direito do Estado. 
Execução e do Processo nesse tema para se obter o que se pode denominar por elementos do processo de execução fiscal.

Este estudo, para tanto, dispõe da seguinte estrutura: num primeiro momento, estuda-se a Jurisdição enquanto função - poder e dever fundamental de pacificar as situações intersubjetivas conflituosas. Nesse ponto, distingue-se a atividade cognitiva da atividade executiva. Após, merece atenção a inexecução obrigacional como fator permissivo da atuação da sanção concreta. Para se criar um liame entre a Jurisdição e a Ação, estuda-se a tutela executiva e a execução fiscal e, nesse ponto, já se amadurece o pensamento para o estudo da natureza jurídica da Ação de Execução Fiscal, considerando o conteúdo da pretensão nela deduzida, ou seja, o crédito regularmente inscrito na Dívida Ativa. Em seguida, estuda-se as condições da ação de execução em geral e da ação de execução fiscal. Nesse momento, um estudo preliminar em torno da natureza do direito da ação se torna conveniente. Como pressuposto prático da Execução Fiscal, estuda-se o título executivo da Fazenda Pública: a Certidão de Dívida Ativa. Por fim, o processo de execução fiscal é estudado pela relação jurídica executiva formada e pelos atos executivos que modificarão a realidade para a satisfação do direito da Fazenda Pública credora.

\section{Jurisdição}

\subsection{Atividade Jurisdicional (função - poder - dever)}

Ninguém será obrigado a fazer ou deixar de fazer alguma coisa senão em virtude de lei (Art. 5ㅇ, II da CF). Trata-se da liberdade fundamental de agir pela qual a todos é permitido tudo o que a norma jurídica não vedar. Mas o que a "lei" veda? Cintra, Grinover e Dinamarco (2000, p. 19) esclarecem que a finalidade da ordem jurídica imposta aos cidadãos é exatamente a de harmonizar as relações sociais intersubjetivas, a fim de ensejar a máxima realização dos valores humanos com o mínimo de sacrifício e desgaste. O critério que deve orientar essa coordenação ou harmonização é o critério do justo e do equitativo, de acordo com a convicção prevalente em determinado momento e lugar. Mas, nem todos os indivíduos integrantes do grupo social agem conforme os ditames contidos na regra jurídica; violam-na, e não é raridade. A esse respeito, Liebman (1968, p. 2) ensina que, nem sempre os homens cumprem as suas obrigações e obedecem aos imperativos de direito, de maneira 
que, a ordem jurídica não seria completa, nem eficaz se não contivesse em si própria aparelhamento destinado a obter coativamente a obediência a seus preceitos. Daí que, a função precípua do Estado é promover o cumprimento da norma imperativamente. De modo que, além de pacificar relações intersubjetivas conflituosas, proporciona a estabilidade e harmonia do ordenamento jurídico vigente.

Havendo recusa a um dever jurídico, o Estado promove a atuação da norma agendi através da função jurisdicional. Dinamarco (2000, p. 185) conceitua a jurisdição como sendo uma das funções do Estado, mediante a qual este se substitui aos titulares dos interesses em conflito, para, imparcialmente, buscar a atuação da vontade do direito objetivo substancial válida para o caso concreto - seja expressando imperativamente o preceito, seja realizando no mundo das coisas o que o preceito dita. Zavascki (2000, p. 36), ademais, ensina que a atividade jurisdicional é a função do Estado destinada a garantir a legitimidade e a efetividade do conjunto da ordem jurídica, e não apenas da norma jurídica incidente em casos concretos. Com esse conceito, todavia, o Autor (2000) adverte que a concepção clássica acerca da jurisdição, qual seja, a atividade estatal de conhecer a lide e a ela aplicar a norma abstrata, não é suficiente para compreendê-la atualmente, isto porque além dessa função, a jurisdição também aprecia questões exclusivamente de direito, notadamente, nas ações de defesa do ordenamento constitucional e nos recursos excepcionais (Extraordinário e Especial), tutelando-se nestes casos o próprio ordenamento jurídico.

A jurisdição é, ao mesmo tempo, função - poder - dever. É função, enquanto atividade destinada a dirimir os conflitos de interesse. Esta função, por sua vez, se reveste de conteúdo imperativo, sendo seu único titular o próprio Estado, posto que se trata de uma das facetas do exercício do poder político. Por fim, diz-se que é um dever, isto porque, se os homens cederam parte de sua liberdade para a formação de um ente tutor do interesse coletivo e do individual, este ente, o Estado, tem o dever de dispor de um mecanismo hábil a compor as controvérsias entre os cidadãos.

\subsection{Atividade cognitiva e executiva}

Pela atividade jurisdicional o Estado-juiz aprecia a pretensão do autor, instaura o contraditório, aprecia a resistência do réu e, ao final, pronuncia qual dos litigantes terá o interesse tutelado. Ao deduzir sua pretensão o demandante almeja uma prestação 
jurisdicional, esta lhe podendo ou não ser favorável. Todavia, para que essa prestação jurisdicional se revista de legitimidade e eficácia mister se faz que o Estado-juiz disponha de mecanismos aptos a prover o objetivo final da pretensão deduzida. Dessa forma, a lide instaurada pode, basicamente, fundar-se na cognição de uma relação de fato que invoca a subsunção de uma regra jurídica abstrata, ou então, na execução do objeto de uma relação jurídica preexistente que clama eficácia plena no mundo dos fatos.

Sobre a distinção entre a atividade cognitiva e a atividade executiva Liebman (1968, p. 38), precisamente esclareceu que :

\begin{abstract}
a função jurisdicional consta fundamentalmente de duas espécies de atividades, muito diferentes entre si; de um lado, o exame da lide proposta em juízo, para o fim de descobrir e formular a regra jurídica concreta que deve regular o caso; de outro lado, as operações práticas necessárias para efetivar o conteúdo daquela regra, para modificar os fatos da realidade do modo a que se realize a coincidência entre a regra e os fatos. Por conseguinte, a natureza e os efeitos dos atos relativos diferem profundamente; na cognição a atividade do juiz é prevalentemente de caráter lógico: êle deve estudar o caso, investigar os fatos, escolher, interpretar e aplicar as normas legais adequadas, fazendo um trabalho intelectual, que se assemelha sob certos pontos de vista, ao de um historiador, quando reconstrói e avalia os fatos do passado. $O$ resultado de tôdas estas atividades é de caráter ideal, porque consiste na enunciação de uma regra jurídica que, reunindo certas condições, se torna imutável (coisa julgada). Na execução, ao contrário, a atividade do órgão é prevalentemente prática e material, visando produzir na situação de fato as modificações aludidas acima [...] (sic).
\end{abstract}

Theodoro junior (2002, p. 4) ressalta que, a atuação do órgão judicial, por isso mesmo, no processo de conhecimento é bem distinta daquela observada no processo de execução, razão pela qual existem a regulamentação e a sistemática próprias de cada um deles. Há, pois, uma evidente distinção entre a atividade cognitiva e a atividade executiva e, conforme acentua Zavascki (2000), essa diferença se funda na finalidade à qual se destinam, ou seja, no conteúdo da pretensão deduzida em juízo. Por outro lado, embora a atividade cognitiva e a executiva se dirijam à finalidades distintas, Theodoro Junior (2002) esclarece que ambas se integram, de sorte que somente assim o provimento jurisdicional revestir-seia de determinação e eficácia plena. E, nesse ponto, Liebman (1968, p. 4) advertiu que, o conhecimento e julgamento da lide (processo de cognição) e a atuação da sanção (processo de execução) são duas formas igualmente importantes da atividade jurisdicional, que se complementam, estando uma a serviço da outra. Julgamento sem execução significaria 
proclamação do direito em concreto sem sua efetiva realização prática; e, por sua vez, execução sem cognição poderia resultar no arbítrio mais evidente.

\subsection{Inexecução obrigacional e execução forçada (sanção concreta)}

O direito objetivo prevê um universo abstrato de normas que incidem sobre as relações jurídicas convencionadas pelos indivíduos, enunciando a existência de um direito material subjetivo. Constituída, pois, uma relação de direito material, os contraentes adquirirão, de um lado, o direito de usar e gozar e, de outro, o dever de prover a prestação convencionada. Theodoro Junior $(2002$, p. 6) ensina que, a coatividade prevista no conteúdo abstrato e genérico da regra de direito transporta-se para o concreto da vida quando uma relação qualquer entre pessoas cai sob área de incidência da norma.

Uma vez não cumprida espontaneamente a prestação que se convencionou exsurge o enunciado secundário da norma, ou seja, a sanção para provocar a ingerência do Estado na esfera dos direitos patrimoniais e pessoais do devedor inadimplente com o objetivo de promover a realização do direito material violado.

Dinamarco (2000, p. 239), releva o fundamento da atuação secundária do Estadojuiz esclarecendo que, se o Estado se limitasse a estabelecer preceitos normativos (abstratos ou mesmo concretos) para reger relações intersubjetivas, certamente restariam muitos casos em que sua vontade não ficaria satisfeita. A experiência demonstra que, muitas vezes, nem toda a forte motivação posta pelo ordenamento jurídico leva ao cumprimento (voluntário) das obrigações. Por isso, o próprio ordenamento dispõe uma série de medidas, através das quais o Estado invade a esfera de autonomia do indivíduo, para propiciar ao titular do direito subjetivo, a custa dele, o bem que o direito material lhe atribui.

Essa consequência lógica inafastável que assegura o cumprimento do enunciado violado é denominada sanção. Zavascki (2000) com extrema clareza, ensina que as normas jurídicas são revestidas de dois preceitos distintos, porém, interligados. O primeiro é a endonorma, ou seja, aquele preceito meramente declarativo de uma prestação. Já o segundo, é denominado perinorma, que é a resposta do ordenamento jurídico tornando certo o cumprimento da endonorma violada. A sanção decorre do próprio exercício pleno do poder político pelo Estado-juiz, que deve atuar na certeza do cumprimento das normas jurídicas. A sanção deve ser adequada e útil a recompor, restituir ou, tão somente, negar ou 
declarar a existência uma situação de incerteza. Para isso, as sanções são adaptadas para instrumentalizar a prestação do direito material violado. Zavascki $(2000$, p. 41) esclarece que as sanções podem ser meramente formais, ou então, concretas. As primeiras são impostas mediante atuação no plano jurídico, como as de constituir, desconstituir, ou modificar uma relação jurídica. Já as sanções concretas demandam para a sua aplicação, providências para manter ou modificar o mundo dos fatos (fazer, desfazer, entregar ou pagar).

$\mathrm{Na}$ execução forçada, há sanções de conteúdo concreto e, conforme acentua Zavascki (2000, p. 41)

quem entende que deve ser tida como de execução qualquer atividade jurisdicional destinada a impor a vontade sancionatória da norma, concluirá que também pertence a esse domínio a imposição das sanções de natureza puramente jurídicoformal, como a de simplesmente anular um ato. Todavia, não é esse o entendimento dominante e nem o que inspirou o sistema do Código de Processo Civil. É que esta espécie de sanção, do primeiro grupo, não demanda subsequente atuação prática dos órgãos jurisdicionais, sendo suficiente para sua realização à modificação do estado jurídico. Na verdade, quando se afirma que a execução forçada é a atuação concreta da vontade sancionatória da norma jurídica, está se referindo apenas às sanções do segundo grupo, ou seja, apenas àquelas que exigem, para sua concretização, providências práticas, materiais, no sentido de adequar o mundo real ao enunciado endonormativo.

Dinamarco (2000) ressalta que a atuação da sanção concreta pressupõe a verificação de situações subjetivas. Estas são ligadas às próprias condições de se provocar a tutela jurisdicional (condições da ação). Dessa forma, o mesmo Autor (2000, p. 293) ensina que não se pode dizer que a aplicação da vontade sancionatória ao caso concreto produza desde logo, efetivamente, o poder do órgão executivo para atuar a sanção, o poder do credor para provocar essa atuação (ação executiva) e a sujeição do devedor a ela. Não há ação se não houver interesse processual e o interesse de agir in executivis só aparecerá no momento em que se conjugarem os dois requisitos da adequação e necessidade da atuação da vontade sancionatória (...).

Com o nascimento de uma relação jurídica de direito material, surge o dever de a prestação que se convencionou, isto porque da existência do direito subjetivo deriva a garantia do seu adimplemento, inclusive coercitivamente por meio da atuação da sanção executiva. 


\subsection{Tutela executiva e execução fiscal}

O Estado se manifesta no mundo jurídico dotado de personalidade jurídica. Tratase, pois, de uma criação do direito positivo para que a entidade política, autárquica ou fundacional possam se relacionar com os outros sujeitos de direito público ou privado, contraindo direitos e obrigações ${ }^{2}$.

Dentre as mais diversas competências atribuídas aos entes estatais está a arrecadação de tributos que serão destinadas a realizar os serviços que satisfarão as necessidades públicas. A Administração Pública promove essa atividade vinculada exigindo do obrigado a realização dessa prestação. Se, no entanto, o obrigado não cumpre com a prestação enunciada na norma tributária ou de outra natureza, surge a necessidade de aplicação do preceito secundário da norma jurídica para que o Estado-juiz promova a atuação da sanção e submeta o patrimônio do obrigado à satisfação do crédito tributário ou não tributário da entidade estatal. Silva Pacheco $(1976$, p. 26) ressalta que

o fato de ser o próprio Estado que tem direito, a pretensão ou ação não autoriza que ele, por si, execute sem invocar o Judiciário, que de forma exaustiva tem a faculdade de jurisdição, que abrange atos executivos. O Estado-administrador, que tem direitos, pretensões e ações pode exigir a prestação do obrigado como qualquer cidadão. Havendo descumprimento, pode o Estado-administrador agir, pelos meios ao seu dispor, dentro da lei material, tributária ou administrativa aplicável, para obter a prestação. É a ação de direito material, inegável, mas que se não confunde com a ação tendente a obter do Judiciário a prestação jurisdicional pertinente ${ }^{3}$.

Consagrando-se as garantias da inafastabilidade da jurisdição e do devido processo legal, Silva Pacheco (1976, p. 26) enfatiza que

2 Código Civil, art 40: As pessoas jurídicas são de direito público, interno ou externo, e de direito privado. Art. 41São pessoas jurídicas de direito público interno: I - a União; II - os Estados, o Distrito Federal e os Territórios; III - os Municípios; IV - as autarquias; V - as demais entidades de caráter público criadas por lei.

3 Mas, em outras épocas, todavia, como relembra VALDER DO NASCIMENTO (2000), existia no Brasil Colônia as Juntas de Fazenda que conjugavam o exercício administrativo de apuração dos créditos e, já os executavam se o contribuinte não adimplesse a obrigação tributária espontaneamente. Não havia atividade jurisdicional para apreciar a lide tributária, ficando o contribuinte a mercê de seu próprio credor, o Estado. O mesmo Autor (2000, p. 4), continua dissertando que, já no Período Imperial, diante das inúmeras falhas cometidas pelas Juntas de Fazenda, reestruturou-se o fisco e assim: (...) houve-se por bem, mediante Alvará, abolir a jurisdição exercitada por elas, passando, então, o Erário e Tesouro Real Público, recém-criado, a ter as mesmas prerrogativas, jurisdição, inspeção, autoridade, obrigações estabelecidas na Carta de Lei que criou o Real Erário de Lisboa. 
não prestada a obrigação, porém, baldas as tentativas amigáveis nesse sentido, não pode o Estado-administrador penhorar, por si, os bens do obrigado ou do contribuinte relapso, ou expropriá-los para satisfazer-se. Há que inscrever a dívida, quando exigida a inscrição, e, com base no fato que a lei tem como relevante para autorizar e causar a execução pelo Judiciário, atuar perante esse, como faz qualquer cidadão, em igualdade de condições, para obter deste a prestação executiva. O Estado-judiciário é que, deferindo a ação executiva, instaura o processo judicial, em ângulo, e de acordo com a lei processual intervém na esfera patrimonial do executado, daí retirando bens suficientes, em caráter satisfativo, para atender ao fim da execução, que é a consumação da prestação jurisdicional executiva.

Martins da Silva (2001, p. 154) ensina que (...)

não resta dúvida de que o Estado de Direito deve ser submetido ao império da lei e, como pessoa jurídica de direito público que é, suas relações de crédito e débito se subordinam aos ditames das normas legais. Por força desse postulado, chega-se a conclusão no sentido de que ele, por si só, não pode, absolutamente, executar suas dívidas, manu militari, pois também ao Estado-administração, ao Estado-fisco, à Fazenda Pública, está vedado fazer justiça pelas próprias mãos. Essa é, inclusive, uma característica do Estado de Direito, ou seja, ficar, como vimos, sujeito ao controle judiciário, razão porque as lides, de que seja um dos sujeitos, hão de ser solucionadas pela atuação da vontade da lei.

Assim, Silva Pacheco (1976, p. 27) esclarece que ação, jurisdição e lei processual são três elementos inconfundiveis no estudo do processo de execução fiscal, como são em todo e qualquer processo judicial.

Os institutos da teoria geral do processo de execução são, essencialmente, os mesmos aplicáveis ao processo de execução fiscal, inclusive porque a natureza da prestação deduzida é a mesma de qualquer execução forçada, ou seja, a satisfação de um crédito líquido, certo e exigível. Todavia, porque o bem da vida pretendido em juízo é indisponível, eis que a Fazenda Pública representa o interesse público, a execução forçada de seus créditos é realizada por meio de um processo e procedimento com matizes especiais, regulado pela Lei Federal n.ㅇ 6.830, de 22 de setembro de 1980 e, subsidiariamente, pela Legislação processual geral (art. 1ํㅡ, da Lei de execução fiscal). 


\section{Execução fiscal}

\subsection{Natureza jurídica}

Toda pretensão nasce da possibilidade de se provocar a atuação da sanção em virtude da violação do preceito primário enunciado em uma norma de direito material. Isto ocorre em qualquer sistema jurídico. Em todo caso, o fundamento básico para se provocar a apreciação pelo Poder Judiciário do conflito de interesses estará insculpido no art. 5ำ XXXV, da Constituição Federal, a saber: a lei não excluirá de apreciação do Poder Judiciário lesão ou ameaça a direito; e no art. 3ำ, do Código de Processo Civil, ou seja, para propor ou contestar ação é necessário ter interesse e legitimidade. A pretensão da Fazenda Pública para provocar a atuação da sanção concreta também se respalda nesses dispositivos e, ainda, no art. 10 da LEF, cuja redação é a seguinte: a execução judicial para cobrança da Dívida Ativa da União, dos Estados, do Distrito Federal, dos Municípios e respectivas autarquias será regida por esta Lei e, subsidiariamente, pelo Código de Processo Civil.

Antes de expor a natureza jurídica da ação de execução fiscal, conveniente é efetuar um esboço das teorias que mais se destacaram ao longo dos tempos acerca do que seria a ação.

A teoria imanentista, desenvolvida por Savigny, concebia a ação como sendo um atributo do próprio direito material, de modo que somente poderia provocar a tutela jurisdicional àquele que, realmente, fosse o titular do direito material subjetivo. Esta teoria conclui que somente há ação se houver um efetivo direito material.

Num segundo momento, Muther, na Alemanha, formulou a teoria de que a ação seria um direito público independente do direito material subjetivo, exercível tanto contra o Estado, titular do exercício do Poder Jurisdicional, como contra o efetivo ofensor do direito material. Muito embora concebida a doutrina da ação como direito abstrato, sua existência somente estaria verificada se, ao final da demanda, o provimento fosse favorável àquele que provocou a atividade jurisdicional, o autor. Esta era a teoria da ação como direito abstrato e concreto formulada por Wach, na Alemanha.

Chiovenda, na Itália, seguindo esta mesma linha de raciocínio formulou a teoria da ação como poder de submissão do ofensor ao interesse do autor. Trata-se de uma forma concretista de promover a vontade da lei. Conforme acentuam Cintra, Grinover e Dinamarco 
(2000), embora Chiovenda sustentasse a inexistência de um efetivo direito, a situação jurídica de criar a referida submissão se revela correlata à existência de um direito de provocá-la.

Degenkolb, na Alemanha, lança mão de uma doutrina, a que concebe a ação como sendo um direito autônomo e abstrato.

Cintra, Grinover e Dinamarco (2000, p. 250) ensinam que,

\begin{abstract}
segundo esta linha de pensamento, o direito de ação independe da existência efetiva do direito material invocado: não deixa de haver ação quando uma sentença justa nega a pretensão do autor, ou quando uma sentença injusta a acolhe sem que exista na realidade o direito subjetivo material. A demanda ajuizada pode ser até temerária, sendo suficiente, para caracterizar o direito de ação, que o autor mencione um interesse seu, protegido em abstrato pelo direito. É com referência a esse direito que o Estado está obrigado a exercer a função jurisdicional, proferindo uma decisão, que tanto poderá ser favorável como desfavorável.
\end{abstract}

Para essa doutrina o único sujeito passivo do direito de ação é o próprio Estado, isto porque ele concentrou em si e exerce exclusivamente o poder de realizar a vontade sancionatória, ou seja, a atuação da perinorma através da atividade jurisdicional.

O italiano Alfredo Rocco, adepto a essa teoria declarou que, além do interesse daquele que provoca a tutela de seu direito violado, existe o interesse secundário do Estado em dirimir aquela situação de incerteza que é prejudicial à harmonia das relações sociais.

Liebman desenvolveu o pensamento de que a ação é um direito subjetivo instrumental, de natureza constitucional. Ademais, é um poder que se exerce contra o Estado, para culminar a controvérsia de direito material.

Atualmente, há o consenso entre os doutrinadores de que a ação é um direito assegurado pela Constituição (art. 5, XXXV), autônomo em relação ao direito material e, a este instrumental, posto que, de seu exercício advirá um provimento jurisdicional para regular a situação concreta enunciada pelo próprio direito material.

Sempre que a Fazenda Pública dispõe de um crédito e o obrigado não o satisfaz espontaneamente, surge o direito abstrato de provocar a tutela jurisdicional executiva para promover a atuação da perinorma que realizará o direito material violado.

No que se refere à modalidade, a ação de execução é, na expressão de Martins da Silva (2001, p. 171) ação de execução singular por quantia certa com procedimento especial, 
porquanto exige-se a existência de um crédito líquido, certo (art. $2^{\circ} \stackrel{\circ}{\S} \S 3^{\circ}$, da $\operatorname{LEF}^{4}$ ). E, conforme ensinamento de Silva Pacheco (2002, p. 10),

\begin{abstract}
a execução judicial, a que se alude o art. 1ํ, e que vai denominada de execução fiscal nos arts. 40, 12, 25 e 26 da lei que comentamos, é a execução singular por quantia certa, com base em título executivo extrajudicial, constituído pela certidão de dívida ativa regularmente inscrita, de caráter expropriatório, que se realiza no interesse da Fazenda Pública, como tal compreendida a União, os Estados, o Distrito Federal, os Municípios e respectivas autarquias.
\end{abstract}

Ademais, é execução forçada singular, porquanto, somente a pessoa jurídica de direito público (União, Estados, Distrito Federal, Municípios, Autarquias e Fundações ${ }^{5}$ ), reconhecida como credora no título executivo integra o pólo ativo da demanda, tudo a teor do disposto no art. 29 da Lei de Execução Fiscal e art. 187 do Código Tributário Nacional com a seguinte redação: a cobrança judicial do crédito tributário não é sujeita a concurso de credores ou habilitação em falência, concordata, inventário ou arrolamento. Embora a repetição dos dispositivos legais acima citados pareça ser uma redundância, isto o é apenas aparentemente. Isto porque o Art. 187, do CTN se refere somente aos tributos, ao passo que a Lei de Execução Fiscal é mais ampla ao abranger todo a Dívida Ativa. Convém, desde já, esclarecer que o objeto do processo de execução fiscal pode ser não só os créditos tributários, mas também todo crédito das pessoas jurídicas de direito público, legitimadas a este procedimento, seja qual for sua origem, desde que, inscritos regularmente como Dívida Ativa.

Estudado a natureza jurídica da ação de execução fiscal, interessante reservar uma parte do presente texto à exposição da origem e desenvolvimento da relação de direito material e do bem da vida tutelado, ou seja, o objeto da pretensão deduzida no processo de execução fiscal.

\footnotetext{
4 Art. 2o (....); §3ㅇ A inscrição, que se constitui no ato de controle administrativo da legalidade, será feita pelo órgão competente para apurar a liquidez e certeza do crédito (...);

5 Somente as Fundações Públicas criadas por lei, como, por exemplo, o Instituto de Terras de São Paulo (ITESP).
} 


\subsection{Pretensão (crédito regularmente inscrito na Dívida Ativa)}

O objeto da ação de execução fiscal é o crédito regularmente inscrito na Dívida Ativa. O bem da vida sobre o qual incide a pretensão do ente público é a quantia pecuniária certa ou outro bem de conteúdo econômico.

A Dívida Ativa do Estado-administrador (Fazenda Pública) provém de créditos tributários ou de créditos não tributários, conforme o disposto no art. 2ํㅡ, caput, da LEF com a seguinte redação: Constitui Dívida Ativa da Fazenda Pública aquela definida como tributária ou não-tributária na Lei 4.320, de 7 de março de 1964, com as alterações posteriores, que estatui normas gerais de direito financeiro para elaboração e controle dos orçamentos e balanços da União, dos Estados, dos Municípios e do Distrito Federal.

Conforme o disposto no art. 39, § 2ํ, da Lei no 4.320, de 17/03/1964, a Dívida Ativa da Fazenda Pública compõe um universo dos créditos derivados, tanto de crédito tributário como de crédito não-tributário. A saber: Dívida Ativa Tributária é o crédito da Fazenda Pública dessa natureza, proveniente de obrigação legal relativa a tributos e respectivos adicionais e multas, e Dívida Ativa não Tributária são os demais créditos da Fazenda Pública.

Constituem Dívida Ativa: (a) Tributárias: impostos (art. 145, I, da CF); taxas (art. 145, II, da CF); contribuições de melhoria (art. 145, III, da CF); empréstimos compulsórios (art.148, caput, da CF); contribuições especiais (art. 149, da CF); (b) Não-tributárias: multa de qualquer origem ou natureza, exceto as tributárias, foros, laudêmios, aluguéis ou taxas de ocupação, custas processuais, preços de serviços prestados por estabelecimentos públicos, indenizações, reposições, restituições, alcances dos responsáveis definitivamente julgados, bem assim os créditos decorrentes de obrigações em moeda estrangeira, de sub-rogação de hipoteca, fiança, aval ou outra garantia, de contratos em geral ou de outras obrigações legais.

Antes da inscrição da obrigação inadimplida na Dívida Ativa, há um procedimento de apuração do crédito que se desencadeia a partir de uma situação de fato, ou seja, de um ato, fato ou negócio jurídico.

Toda situação de fato que repercute no universo abstrato de direito positivo é qualificada por fato jurídico. O fato adquire uma identidade jurídica e, essa atração que se opera entre o fato e a norma que o descreve torna-se irrefutável. A norma jurídica abstrata 
em repouso ganha vida e se manifesta no mundo dos fatos. É o que se denomina subsunção a norma abstrata ao fato concreto ${ }^{6}$.

Martins da Silva (2001, p. 45) ensina que:

a constituição da Dívida Ativa implica em acertamento da incidência da norma tributária ou da norma não tributária, conforme o caso. As normas se enunciam de forma abstrata e as situações em que elas incidem são concretas. É necessário, portanto, uma razoável certeza na adequação da norma abstrata à situação concreta $[\ldots]$.

Nesse quadro, toda relação jurídica de direito substancial nasce pela ocorrência de um fato, ato ou mesmo negócio jurídico. Isto porque, conforme ressalta Martins da Silva (2001, p. 46), o acertamento do preceito leva ao acertamento da obrigação. ${ }^{7}$ Com efeito, o mesmo Autor (2001, p. 47), conclui que, a obrigação, tanto tributária como não-tributária, caracteriza-se, pois, como resultante da incidência do preceito, quando constatada a coincidência de uma situação de vida com a hipótese prevista na norma.

Villaça Azevedo (2000, p. 31) conceitua obrigação como sendo a relação jurídica, de caráter transitório, estabelecida entre devedor e credor e cujo objeto consiste numa prestação pessoal econômica, positiva ou negativa, devida pelo primeiro ao segundo, garantindo-Ihe o adimplemento através de seu patrimônio.

Verificada a situação de fato que, hipoteticamente, deu origem a uma obrigação tributária ou não tributária, surge a necessidade de desencadear a atividade administrativa tendente a apuração da existência da obrigação de dar e o objeto da prestação e o montante dessa prestação. Em outras palavras, inicia-se o lançamento do crédito, conforme o disposto no art. 53, da Lei Federal no 4.320, de 17/03/1964, ou seja, o lançamento da receita, é ato da repartição competente, que verifica a procedência do crédito fiscal e a pessoa que lhe é devedora e inscreve o débito desta. Martins da Silva (2001) esclarece que a procedência do

6 No âmbito do direito tributário a previsão de uma norma abstrata que regula uma situação de fato é denominada hipótese de incidência. Já a situação de fato que dá origem à obrigação tributária, a teor do disposto no art. 114, do CTN, recebe a denominação de fato gerador. Assim, fato gerador da obrigação principal é a situação definida em lei como necessária e suficiente à sua ocorrência.

7 A atividade de apuração dos elementos formadores da obrigação tributária é, conforme o disposto no art. 142, do CTN, denominada lançamento (Art. 142. Compete privativamente à autoridade administrativa constituir o crédito tributário pelo lançamento, assim entendido o procedimento administrativo tendente a verificar a ocorrência do fato gerador da obrigação correspondente, determinar a matéria tributável, calcular o montante do tributo devido, identificar o sujeito passivo e, sendo caso, propor a aplicação da penalidade cabível). 
crédito é o mesmo que existência da obrigação e, quando o dispositivo se refere em inscrever o débito, significa aquele crédito reconhecido, porém, inadimplido provocando a sua inscrição em Dívida Ativa.

Martins da Silva (2001, p. 54) enumera os motivos e a finalidade do lançamento: (a) constatar a existência do fato que deu origem à obrigação tributária ou não tributária; (b) determinar a natureza dessa obrigação; (c) apurar o montante devido; (d) identificar o sujeito passivo da obrigação; e (e) aplicar as penalidades, se cabível no caso.

O lançamento é ato vinculado (art. 142, parágrafo único, do CTN) imprescindível para a apuração do crédito, porquanto, a Administração Pública somente pode proceder à exação precedida do controle de legalidade e legitimidade do ato. Martins da Silva (2001, p. 55) nesse mesmo sentido ensina que, (...) não obstante o crédito seja uma decorrência da obrigação tributária principal, impõe-se ao Estado, como sujeito ativo desta, através de seus agentes, proceder ao respectivo lançamento constituindo-o regularmente sem o que não há como pretender sua exigibilidade.

Diante de todas essas considerações conclui-se que o lançamento é atividade destinada a apurar a certeza e a liquidez do crédito tributário ou não tributário. Com efeito, Martins da Silva (2001, p. 68) aduz que, certeza refere-se a existência de alguma coisa; é a qualidade do que não pairam dúvidas sobre a sua existência. Certeza do crédito é a determinação precisa da existência do crédito documental ou não. Liquidez refere-se ao quantum, a disponibilidade de recursos ou a capacidade de pagamento.

Uma vez constituído definitivamente o crédito tributário ou não tributário, cumpre ao obrigado (contribuinte ou responsável) ${ }^{8}$ executar a obrigação com a realização da prestação devida.

A teor do disposto no art. 160, do Código Tributário Nacional, quando a legislação tributária não fixar o tempo de pagamento, o vencimento do crédito ocorre trinta dias depois da data em que se considera o sujeito passivo notificado do lançamento.

Martins da Silva (2001, p. 71) adverte que

8 Art. 121, do CTN: sujeito passivo da obrigação principal é a pessoa obrigada ao pagamento de tributo ou penalidade pecuniária.

Parágrafo único. O sujeito passivo da obrigação principal diz-se:

I - contribuinte, quando tenha relação pessoal e direta com a situação que constitua o respectivo fato gerador;

II - responsável, quando, sem revestir a condição de contribuinte, sua obrigação decorra de disposição expressa de lei. 
o aviso de lançamento é a materialização da exigência do cumprimento da obrigação tributária formulada ao sujeito passivo ou contribuinte, titular do interesse a ser submetido. O prazo estabelecido pela notificação encontra justificativa no dever da autoridade administrativa de conceder tempo suficiente para o sujeito passivo conferir o acertamento do lançamento do crédito tributário

Após o vencimento do prazo legal ou convencional para o adimplemento do crédito e, não havendo a existência de qualquer causa suspensiva ${ }^{9}$, este se torna exigível. A inadimplência do contribuinte ou responsável autoriza a provocação da tutela jurisdicional executiva para promover a satisfação forçada do crédito inadimplido espontaneamente.

Para a Fazenda Pública valer-se do procedimento especial previsto na Lei Federal no 6.830, de 22/09/1980, é imprescindível a inscrição do débito na Dívida Ativa. E, a teor do disposto no art. 201, do CTN, constitui dívida ativa tributária a proveniente de crédito dessa natureza, regularmente inscrita na repartição administrativa competente, depois de esgotado o prazo fixado, para pagamento, pela lei ou por decisão final proferida em processo regular.

Inicia-se um novo procedimento administrativo com o objetivo de efetuar a referida inscrição do débito na Dívida Ativa e confecção do título executivo (certidão de dívida ativa, conforme o disposto no já mencionado art. 585, VI, do CPC).

Martins da Silva (2001) ensina que inscrição é o procedimento administrativo, que habilita a Fazenda Pública a entrar em juizo, a fim de executar o sujeito passivo ou responsável, com um título líquido e certo, imediatamente exigível, sob pena de penhora. Em outras palavras, o crédito tributário, se não for pago administrativamente às repartições arrecadadoras, dentro do prazo legal ou resultante de decisão do processo do qual ele provenha, converte-se em "dívida ativa" da Fazenda pelo procedimento da "inscrição" nos livros da repartição competente para isso.

Silva Pacheco (2002, p. 41) complementa que, com referência aos créditos da Fazenda Pública e, por extensão, aos das autarquias, a inscrição constitui prévia constatação

\footnotetext{
Art. 151, do CTN: suspendem a exigibilidade do crédito tributário:

I - moratória;

II - o depósito do seu montante integral;

III - as reclamações e os recursos, nos termos das leis reguladoras do processo tributário administrativo;

IV - a concessão de medida liminar em mandado de segurança.

V - a concessão de medida liminar ou de tutela antecipada, em outras espécies de ação judicial;

VI - o parcelamento.
} 
administrativa da legalidade da dívida ativa, quanto à existência e ao seu valor, assim como os adicionais incidentes, tais como juros, multa, correção e outros encargos legais.

Conforme o disposto no art. $2^{\circ}, \S 33^{\circ}$, da LEF, o procedimento de inscrição da dívida ativa é realizado pelo órgão de representação judicial da respectiva Fazenda Pública. ${ }^{10}$ Inscrita a dívida ativa, extrai-se a respectiva certidão de dívida ativa que é o título executivo que autoriza a provocação da tutela executiva.

Martins da Silva (2001, p. 94) esclarece que (...) a certidão extraída do respectivo livro da repartição arrecadadora, de onde consta a inscrição da dívida de origem fiscal, financeira, patrimonial, industrial ou contratual, constitui título executivo público extrajudicial hábil para a Fazenda Pública entrar em juízo com a sua pretensão fundada de fato e de direito.

\subsection{Condições da ação de execução fiscal}

Embora reconhecido o direito constitucional de deduzir uma pretensão perante o Poder Judiciário sempre que houver lesão ou ameaça de lesão a direito (Art. 5ํ, XXXV, da CF), o próprio ordenamento jurídico impõe condições subjetivas e objetivas para que haja a possibilidade de provocação da tutela jurisdicional. São as denominadas condições da ação: legitimidade, interesse de agir e possibilidade jurídica do pedido. A primeira delas é subjetiva, porquanto, considera a identidade do titular do interesse deduzido, ou seja, o titular do bem da vida sobre o qual recai-se a pretensão. Já as duas últimas, são objetivas, pois são consideradas em relação ao próprio objeto da pretensão e a viabilidade dessa pretensão.

Para a instauração de qualquer processo judicial é imprescindível a existência das condições da ação, pois do contrário dever-se-á declarar carente a pretensão deduzida.

10 Lei Complementar (Federal) no 73, de 10/02/1993: Art. 12 - À Procuradoria-Geral da Fazenda Nacional, órgão administrativamente subordinado ao titular do Ministério da Fazenda, compete especialmente:

I - apurar a liquidez e certeza da dívida ativa da União de natureza tributária, inscrevendo-a para fins de cobrança, amigável ou judicial;

Lei Complementar (Estadual) no 478, de 10/07/1986: Art. Artigo 2o - A Procuradoria Geral do Estado, órgão integrante da Secretaria da Justiça,(1) tem, com fundamento nos artigos 48 a 51 da Constituição do Estado, as seguintes atribuições:

$\mathrm{VI}$ - promover privativamente a cobrança da dívida ativa em todo o Estado; 
A teor do disposto no art. 10 da LEF, conjugado com os arts. 566, I, e 585, VI, do $\mathrm{CPC}^{11}$, somente a Fazenda Pública pode promover a ação de execução, ou seja, a União, os Estados, o Distrito Federal, os municípios, as entidades autárquicas e as fundacionais (com personalidade jurídica de direito público). Já em se tratando de legitimidade ad causam passiva, o art. 4ํㅡㄹ da LEF elenca o rol dos então legitimados para figurar no pólo passivo da ação ${ }^{12}$.

A possibilidade jurídica do pedido é, na expressão de Shimura $(1997$, p. 68) a previsão legal abstratamente prevista em lei, ou não negada pelo sistema. É a possibilidade de o pedido ser atendido, porque abstratamente, vem regulado por lei. Destarte, o título executivo comporta esta condição. É importante, todavia, esclarecer que o título executivo em si não se coincide com a possibilidade jurídica do pedido, de modo que ele atesta a existência de uma relação jurídica tutelada, pois, pelo direito positivo. Em se tratando de execução fiscal, a possibilidade jurídica do pedido funda-se na existência de uma obrigação tributária ou não tributária reconhecida em lei à qual não foi adimplida espontaneamente pelo sujeito do interesse subordinado.

O interesse de agir é verificado pelo inadimplemento da obrigação contida no título executivo, revelando-se a necessidade e utilidade da prestação da tutela executiva jurisdicional. Shimura (1997, p. 60) ensina que

o interesse de agir liga-se à necessidade concreta da jurisdição (exigibilidade) e à adequação da via procedimental (titulação). Surge da necessidade de obter a tutela jurisdicional, por meio do processo, utilizando-se o procedimento legal adequado. Em outros termos, é da exigibilidade do título que nasce a necessidade concreta da execução.

11 Art. 566. Podem promover a execução forçada:

I - o credor a quem a lei confere título executivo;

Art. 585. São títulos executivos extrajudiciais:

(...)

VI - a certidão de dívida ativa da Fazenda Pública da União, Estado, Distrito Federal, Território e Município, correspondente aos créditos inscritos na forma da lei;

12 Art. 4ㅇ - A execução fiscal poderá ser promovida contra:

I - o devedor;

II - o fiador;

III - o espólio;

IV - a massa;

V - o responsável, nos termos da lei, por dívidas, tributárias ou não, de pessoas físicas ou pessoas jurídicas de direito privado; e

$\mathrm{VI}$ - os sucessores a qualquer título 
O interesse de agir está previsto no art. 580, do CPC. O dispositivo estabelece que verificado o inadimplemento do devedor, cabe ao credor promover a execução.

\subsection{Título executivo (Certidão de Dívida Ativa)}

Estudadas as condições da ação de execução fiscal, interessante, outrossim, destinar uma parte do presente artigo ao estudo do título executivo que autoriza a execução forçada dos créditos tributários ou não tributários: a Certidão de Dívida Ativa.

Conforme o disposto no art. 583, do CPC, toda execução tem por base título executivo judicial ou extrajudicial. Dissertou-se na Subseção supra que, a possibilidade jurídica do pedido não se confunde com o próprio título executivo. Este é tão só uma declaração da existência de um crédito líquido e certo, porém, inadimplido pelo sujeito do direito subordinado, culminando na frustração do direito do credor que, deve provocar a atuação da sanção concreta para a satisfação de sua pretensão.

Theodoro Junior (2002) ressalta a finalidade do título executivo: permitir a execução forçada; definir o procedimento executivo e, por fim, delimitar os elementos da execução. ${ }^{13}$ A finalidade precípua do título executivo é autorizar a atuação da sanção concreta. A esse respeito Assis (2000, p. 133) aduz que o princípio nulla executio sine titulo, previsto no art. 583, se justifica ante a necessidade de que a invasão da esfera jurídica do executado repouse em direito provável. A exibição do título representa a forte razão que autoriza a penetração no patrimônio. Ademais, o Autor (2000) ressalta que a eficácia do título executivo decorre de previsão expressa em lei, tornando-se, pois, desnecessária a prova do crédito. Por conseguinte, o título executivo declara o direito material e demonstra qual o procedimento hábil para torná-lo efetivo no mundo dos fatos. Theodoro Junior (2002, p. 28), a esse respeito, enuncia que é o título executivo que define o fim da execução porque é ele que revela qual foi a obrigação contraída pelo devedor e qual a sanção que corresponde a seu inadimplemento, apontando dessa forma, o fim a ser alcançado no procedimento executivo. Por fim, Theodoro Junior (2002) ensina que o título executivo fixa os limites subjetivos e objetivos para que a prestação jurisdicional não seja realizada ultra, extra ou citra petita.

13 THEODORO JUNIOR ensina que a execução forçada, como qualquer outra ação comporta tanto elementos subjetivos como elementos objetivos: naqueles estão as partes (exequente e executado) e o órgão do poder jurisdicional. Nestes, por sua vez, estão englobados, além do objeto do litígio, os bens e o arcabouço probatório. 


\title{
3 Processo
}

\subsection{Processo e procedimento}

Para o desenvolvimento de um estudo científico acerca do processo e do procedimento, mister se faz reservar uma parte do texto à análise, ainda que breve, da natureza jurídica de cada um e da sua finalidade.

Sob o aspecto político, o processo é instituição do Estado democrático de direito; decorre da própria soberania e sua finalidade é a apreciação dos conflitos inter-subjetivos para a composição da lide sob a observância de um método defeso a qualquer arbitrariedade.

Sob o aspecto jurídico, o processo é, conforme ensinam Cintra, Grinover e Dinamarco (2000), relação jurídica de direito público desenvolvida entre o Demandante, o Estado-juiz e o Demandado.

Os Autores (2000, p. 280) advertem que, atualmente, a teoria do processo como relação jurídica formulada por Büllow, em 1868, é ainda a mais razoável porque

\begin{abstract}
é inegável que o Estado e as partes estão, no processo, interligados por uma série muito grande e significativa de liames jurídicos, sendo titulares de situação jurídica em virtude das quais se exige de cada um deles a prática de certos atos do procedimento ou lhes permite o ordenamento jurídico essa prática; e a relação jurídica é exatamente o nexo que liga dois ou mais sujeitos, atribuindo-lhes poderes, direitos, faculdades, e os correspondentes deveres, obrigações, sujeições, ônus. Através da relação jurídica, o direito regula não só os conflitos de interesse entre as pessoas, mas também a cooperação que estas devem desenvolver em benefício de determinado objetivo comum.
\end{abstract}

Não se deve confundir o processo com o procedimento. Enquanto aquele é a relação dinâmica entras as partes e o Estado-juiz, todos com o mesmo objetivo de buscar a composição da lide, este é a forma com que os sujeitos do processo valer-se-ão para obter com maior segurança um provimento final legítimo. O procedimento, pois, é, na expressão de Cintra, Grinover e Dinamarco (2000, p. 275) o meio pelo qual a lei estampa os atos e fórmulas da ordem legal do processo. 


\title{
3.2 Relação jurídica executiva
}

Proposta a ação de execução fiscal para a satisfação forçada do crédito não adimplido espontaneamente pelo agora executado, nasce uma relação jurídica entre a exequente (Fazenda Pública), executado e o Estado-juiz.

Theodoro Junior (2001, p. 59), esclarece que a pendência do processo dá lugar, entre seus participantes, a uma relação jurídica, que é a relação jurídica processual, gerando uma série de direitos e deveres, denominados pelas doutrina direitos e deveres processuais (...). E, Liebman (1968, p. 38), ressaltou as características fundamentais da relação jurídica executiva, cotejando-a com a relação processual desencadeada no processo de cognição a partir dos seguintes termos aduzindo que

\begin{abstract}
a posição jurídica das partes também é diferente. Na cognição elas estão em posição de igualdade e de equilíbrio, pois não se sabe qual delas está com razão, e nada pode ser feito, sem que tôdas elas sejam ouvidas ou possam fazer-se ouvir, de acordo com o princípio do contraditório: tôdas cooperam, cada uma no sentido do próprio interêsse, para as investigações do juiz, procurando convencê-lo da procedência das alegações que elas apresentam; mas o resultado de todo êste trabalho conjunto poderá ser afinal favorável tanto a uma quanto à outra. Muito pelo contrário, na execução não há mais equilíbrio entre as partes, não há contraditório; uma delas foi condenada e sôbre este ponto não pode mais, em regra, haver discussão; a outra, tendo conseguido o reconhecimento de seu direito, exige que se proceda de acôrdo com o que a sentença declarou e o condenado não o pode impedir deve suportar o que se faz em seu prejuízo, sendo ouvido só na medida em que a sua colaboração possa ser útil e podendo pretender unicamente que os dispositivos da lei não sejam ultrapassados no cumprimento desta atividade. É certo que a controvérsia e o contraditório podem reaparecer, mas isto somente em nôvo processo de cognição de caráter incidente (embargos) (sic).
\end{abstract}

A despeito desse ensinamento, Dinamarco (2000), considerando a nova ordem constitucional vigente, aduz que, no processo de execução, embora a atividade jurisdicional parta de premissa de submeter o interesse do executado ao interesse do exequente ${ }^{14}$, ainda assim, os sujeitos do processo interagem todos com direitos subjetivos, ônus e deveres processuais, sem que haja desvio da finalidade precípua do processo de execução. Até porque sem a observância do contraditório, por consequência, do devido processo legal, a relação jurídica executiva revestir-se-á de flagrante ilegalidade, a ponto de tornar o provimento final ilegítimo perante a ordem jurídica constitucional. Assim, tanto o exequente

14 Código de Processo Civil, art. 612: ressalvado o caso de insolvência do devedor, em que tem lugar o concurso universal (art. 751, III), realiza-se a execução no interesse do credor, que adquire, pela penhora, o direito de preferência sobre os bens penhorados. 
como o executado, relacionam-se entre si e com o Estado-juiz com a finalidade de que o processo de execução fiscal distribua, em última análise, a justiça social, não impondo a ordem jurídica um provimento revestido de injustiça.

Tornou-se assente no cotidiano forense a possibilidade do executado ilidir a pretensão da Fazenda Pública por um incidente usualmente intitulado "exceção de préexecutividade", sem a garantia do juízo conforme exige o art. $16, \S 1$ o da LEF. A resistência carreada neste incidente somente pode versar sobre matérias de ordem pública que não exigem dilação probatória, exempli gratia, decadência e prescrição ${ }^{15}$.

Para sopesar a premissa irradiada do já citado art. 612, do Código de Processo Civil, existe a norma contida no art. 620 , do mesmo codex, com o seguinte preceito: quando por vários meios o credor puder promover a execução, o juiz mandará que se faça pelo modo menos gravoso para o devedor.

\subsection{Atos executivos}

Já se disse supra que a atividade jurisdicional é desenvolvida conforme o objeto da pretensão deduzida. Ou seja, se a lide versa sobre uma situação à qual o órgão jurisdicional deva declarar às partes o direito positivo aplicável, o Estado-juiz desenvolverá a atividade cognitiva. Mas, se já existe uma norma de direito substancial, mas que, ainda não produziu efeitos no mundo dos fatos, o Estado-juiz deverá promover a atividade executiva para tornála efetiva ${ }^{16}$. Com efeito, Assis (2000, p. 105) esclarece que a função jurisdicional executiva exige, preponderantemente, a transformação do mundo dos fatos. O mesmo Autor (2000, p. 105), esclarece que

essas modificações fáticas requerem, por sua vez, a invasão da esfera jurídica do executado, e não só seu círculo patrimonial, porque, no direito pátrio, os meios de coerção, além da finalidade tradicional de arredar obstáculos á realização do

15 PROCESSUAL CIVIL. EXECUÇÃO FISCAL. EXCEÇÃO DE PRÉ-EXECUTIVIDADE. CABIMENTO.

1. Em princípio, a defesa do executado deve realizar-se através dos embargos, nos termos do art. 16 da Lei de Execução Fiscal. Todavia, é assente na doutrina e na jurisprudência o cabimento de exceção de préexecutividade quando a parte argüi matérias de ordem pública ou nulidades absolutas que dispensam, para seu exame, dilação probatória. Esse entendimento objetiva atender ao interesse público quanto à economia e celeridade processual. Precedentes.

2. Recurso especial conhecido em parte, e nessa parte, improvido. (STJ - REsp. no 410.755/SC - 2a Turma Rel. Min. Castro Meira - j. 14/09/2004 - Data da Publicação DJ 25.10.2004 p.00277)

16 Código de Processo Civil, art. 577: "não dispondo a lei de modo diverso, o juiz determinará os atos executivos e os oficiais de justiça os cumprirão." 
direito, também visam obter o bem da vida, mediante pressão psicológica. Enquanto a medida dos atos do processo de conhecimento é seu conteúdo decisório, a do ato executivo consiste na força.

Trata-se da atuação da sanção concreta, ou seja, do preceito secundário da norma jurídica - perinorma - que, conforme ensina Zavascki (2000, p. 154) sempre que esta sanção consistir em providências materiais, práticas, concretas, de modificação da realidade, sua imposição ocorre mediante processo de execução forçada. Ao conjunto dessas providências estatais dá-se o nome de atos executivos.

Os atos executivos são, portanto, os atos jurídicos processuais realizados para modificar a realidade fática, pondo-a em simetria com o preceito enunciado pela norma jurídica abstrata.

Zavascki (2000) disserta que os atos executivos decorrem do poder de império do Estado que tem interesse em dar efetividade ao direito reconhecido pelo ordenamento jurídico. Daí que, os atos executivos são imponíveis não só às partes - exequente e executado - como também, aos sujeitos forâneos à lide, mas que guardem qualquer interesse jurídico em relação à execução forçada.

O Autor (2000, p. 143) esclarece que

[...] O caráter cogente destas imposições, cuja recusa de cumprimento pode inclusive acarretar sanções penais (CPC, art. 662 e CP, arts. 329 e 330) ${ }^{17}$, tem sua matriz legitimadora no fundamento de que o poder de imperium é exercido para dar efetividade aos preceitos normativos, de modo a fazer cumprir a autoridade da lei, pressupostos indispensáveis à sobrevivência da sociedade organizada.

Quando estudada a natureza jurídica da ação de execução fiscal, dissertou-se que a mesma se trata de execução singular por quantia certa contra devedor solvente e, se insolvente, não sujeita a concurso de credores ${ }^{18}$. No entanto, conforme o disposto no art. 29, parágrafo único, da Lei de Execução Fiscal, admite-se o concurso de preferência entre as

17 CPC, art. 662: "sempre que necessário, o juiz requisitará força policial, a fim de auxiliar os oficiais de justiça na penhora dos bens e na prisão de quem resistir à ordem."

Código Penal, art. 329: "opor-se à execução de ato legal, mediante violência ou ameaça a funcionário competente para executá-lo ou a quem lhe esteja prestando auxílio: Pena - detenção, de 2 (dois) meses a 2 (dois) anos. § 1‥ Se o ato, em razão da resistência, não se executa: Pena - reclusão, de 1 (um) a 3 (três) anos. § 2․ As penas deste artigo são aplicáveis sem prejuízo das correspondentes à violência." $\mathrm{CP}$, art. 330: "desobedecer a ordem legal de funcionário público: Pena - detenção, de 15 (quinze) dias a 6 (seis) meses, e multa."

Lei de Execução Fiscal, arts. 10 e 29. 
pessoas jurídicas de direito público interno na seguinte ordem: I- União e suas autarquias; IIEstados, Distrito Federal e Territórios e suas autarquias, conjuntamente e por rateio e, por fim, IIIMunicípios e suas autarquias, conjuntamente e por rateio.

A teor do disposto no art. 646, do CPC, a execução por quantia certa tem por objeto expropriar bens do devedor, a fim de satisfazer o direito do credor (art. 591). Martins da Silva (2001, p. 482) conceitua a expropriação como sendo o meio legal previsto no Código de Processo Civil para promover a transferência patrimonial forçada de parte do patrimônio do devedor com destino ao patrimônio do credor, de forma a acrescê-lo.

É do ato jurisdicional decorrente da soberania do Estado que substitui a vontade do executado extraindo uma porção de seu patrimônio, o tanto quanto necessário para a satisfação do direito do credor. Ou, conforme o disposto no art. 10, da Lei de execução fiscal: não ocorrendo o pagamento, nem a garantia da execução de que trata o art. 9o, a penhora poderá recair em qualquer bem do executado, exceto os que a lei declare absolutamente impenhoráveis.

A expropriação é ato processual realizado já na fase satisfativa do procedimento executivo fiscal. Por outro lado, a satisfação forçada do direito do credor é deflagrada pela constrição do patrimônio sujeito à ulterior expropriação.

Os atos executivos de constrição do patrimônio do devedor são o arresto e a penhora $^{19}$. Aquele é ato executivo, cuja finalidade é assegurar o resultado útil da futura penhora. Destarte, a figura do arresto surge quando a formalização da penhora se revela, momentaneamente, prejudicada, de sorte que, sem o qual a pretensão do credor é posta em provável risco de frustração. Esta, por sua vez, é ato executivo destinado a individualizar e indisponibilizar a porção do patrimônio do devedor que será expropriada para a satisfação do direito do credor.

Silva Pacheco (2002), com extrema clareza, descreve a finalidade da penhora pelos seguintes elementos: (a) limita o poder de dispor; (b) acarreta a sub-rogação, pelo Estado, do poder de dispor da coisa penhorada; (c) visa atender a execução, tendendo a satisfazêla; (d) tem caráter judicial, forçado e coativo; (e) encaminha-se ao objeto da execução; (f)

19 A Fazenda Pública pode ainda propor a ação cautelar fiscal consoante dispõe a Lei Federal no 8.397/92 para assegurar o resultado prático do futuro processo de execução fiscal. "Futuro" porque, uma vez ajuizado o executivo fiscal, torna-se inviável o arresto cautelar de modo que a Fazenda Pública pode requerer, pura e simplesmente, a penhora sobre o patrimônio do executado. 
individualiza e localiza os bens sobre os quais recai a execução, e (g) limita o gozo, por parte do executado, do bem penhorado.

A penhora dos bens do executado provoca a individualização do patrimônio, em exata proporção ao débito, tornando-o indisponível. E, o principal efeito é tornar indisponível o bem penhorado, de modo que o direito de propriedade fica obstado em relação ao poder de dispor. Todavia, que essa indisponibilidade não é absoluta, de sorte que a alienação de bem penhorado é convalidada quando a penhora for levantada ou quando existir outro bem suscetível de constrição, o que lhe retira a qualidade de objeto do processo de execução fiscal.

Aperfeiçoada a penhora e sendo necessária a expropriação do bem constrito o Código de Processo Civil estabelece em seu art. 647, as modalidades de desapropriação judicial; tais são: I - na alienação de bens do devedor; II - na adjudicação em favor do credor, e III - no usufruto de imóvel ou de empresa.

A primeira hipótese de expropriação é pela arrematação e, na expressão de Martins da Silva (2001, p. 485) trata-se de uma venda judicial dos bens penhorados; é o ato de adquirir um bem, transferido pelo Poder Público a quem oferecer melhor preço. A arrematação é, pois, um procedimento de que dispõe o Estado para promover a alienação dos bens penhorados para evitar que essa alienação se revele ilegítima.

A arrematação é, pois, realizada por meio de leilão ${ }^{20}$, conforme o disposto nos arts. 22 e 23, da Lei de Execução Fiscal; a saber: Art. 22 - A arrematação será precedida de edital, afixado no local de costume, na sede do Juízo, e publicado em resumo, uma só vez, gratuitamente, como expediente judiciário, no órgão oficial. § 1으 - O prazo entre as datas de publicação do edital e do leilão não poderá ser superior a 30 (trinta), nem inferior a 10 (dez) dias. $§ 2$ - O representante judicial da Fazenda Pública, será intimado, pessoalmente, da realização do leilão, com a antecedência prevista no parágrafo anterior. Art. 23 - A alienação de quaisquer bens penhorados será feita em leilão público, no lugar designado pelo Juiz. § 1으 - A Fazenda Pública e o executado poderão requerer que os bens sejam leiloados englobadamente ou em lotes que indicarem. $\S 2$ - Cabe ao arrematante o pagamento da comissão do leiloeiro e demais despesas indicadas no edital. 20 A Lei de Execução Fiscal não acolheu a distinção que se faz da alienação de bens móveis (leilão) da de bens
imóveis (hasta pública), adotando tão somente a denominação "leilão". 
A segunda hipótese de alienação do bem penhorado é pela sua adjudicação. Martins da Silva (2001, p. 561) conceitua esse instituto como sendo o ato de conceder, por decisão judicial, a adjudicação de um bem, ou seja, é declarar judicialmente que certo bem, móvel ou imóvel passa a pertencer a determinada pessoa. Na execução, adjudicação significa o ato judicial de assegurar ao credor a propriedade de bens que deveriam ir ou foram levados a leilão.

A Lei de Execução Fiscal, estabelece em seu art. 24, a possibilidade da Fazenda Pública adjudicar o bem penhorado. Este dispositivo enuncia que: Art. 24 - A Fazenda Pública poderá adjudicar os bens penhorados: I - antes do leilão, pelo preço da avaliação, se a execução não for embargada ou se rejeitados os embargos; II - findo o leilão: (a) se não houver licitante, pelo preço da avaliação; b) havendo licitantes, com preferência, em igualdade de condições com a melhor oferta, no prazo de 30 (trinta) dias. Parágrafo Único Se o preço da avaliação ou o valor da melhor oferta for superior ao dos créditos da Fazenda Pública, a adjudicação somente será deferida pelo Juiz se a diferença for depositada, pela exeqüente, à ordem do Juízo, no prazo de 30 (trinta) dias.

A adjudicação é instituto que faculta à Fazenda Pública credora a possibilidade de se apropriar do bem penhorado, por conveniência e oportunidade, quando for útil à Administração Pública ou não houver outra solução à satisfação do crédito em execução.

Essas são, portanto, as formas mais corriqueiras de satisfação do crédito fiscal.

\section{Conclusão}

1- O processo de execução fiscal representa uma garantia fundamental pela qual o devedor somente será despojado do seu patrimônio na exata proporção do seu débito e pelo meio menos gravoso aos seus direitos.

2- Diante da relação de direito material - obrigação tributária ou não-tributária cumpre ao Estado provocar a tutela jurisdicional para fazer atuar a sanção concreta - o preceito secundário da norma jurídica - que substituirá a vontade do executado e adimplirá o crédito tributário ou não-tributário regularmente inscrito em dívida ativa.

3- Cognição e execução são atividades interligadas destinadas a dar efetividade ao Processo de Execução Fiscal. 
4- O interesse público exige que a execução da dívida ativa da Fazenda Pública se dê por um processo e procedimento especial, no qual o direito do credor - o Poder Público tenha garantia de adimplemento sem a intromissão de qualquer sujeito forâneo à lide. Por isso, a Execução Fiscal se constitui numa execução por quantia certa contra devedor solvente e, se insolvente, não sujeita ao concurso de credores - quando o ajuizamento da ação se deu antes da quebra.

5- O pressuposto prático para se deflagar o executivo fiscal é a Certidão de Dívida Ativa, título executivo extrajudicial de produção unilateral pela Fazenda Pública - assegurado o devido processo legal administrativo - dotado de certeza, liquidez e exigibilidade.

Sua característica maior é a presunção relativa de certeza e liquidez afastável somente a cargo do executado ou de qualquer sujeito com interesse jurídico.

6- O Processo de Execução Fiscal é uma relação jurídica de direito instrumental na qual as partes - Estado e executado - exercem direitos e se sujeitam a deveres e ônus em busca da solução equitativa da demanda. Efetivados os atos executivos e realizado, pois, o direito do credor pelo meio menos gravoso ao devedor, encerra-se a prestação jurisdicional.

7- São esses o que se pode denominar por Elementos do Processo de Execução Fiscal. O estudo à luz da teoria geral do processo, nos aspectos da Jurisdição, Execução e Processo, possibilita uma compreensão mais efetiva do instrumento da Fazenda Pública para a satisfação forçada de seus créditos fiscais.

\section{Referências}

AMARO, Luciano. Direito tributário brasileiro. 9.ed. São Paulo: Saraiva, 2003.

ASSIS, Araken de. Comentários ao Código de Processo Civi. V. VI: arts. 566 a 645. Rio de Janeiro: Forense, 2000.

CINTRA, Antônio Carlos de Araújo; GRINOVER, Ada Pellegrini;DINAMARCO, Cândido Rangel. Teoria geral do processo. 16. ed. São Paulo: Malheiros, 2000.

DINAMARCO, Cândido Rangel. Execução civil. 7. ed. São Paulo: Malheiros, 2000.

LIEBMAN, Enrico Tulio. Processo de execução. 3. ed. São Paulo: Saraiva, 1968. 
MARTINS DA SILVA, Américo Luís. A execução da dívida ativa da fazenda pública. São Paulo: Revista dos Tribunais, 2001.

SILVA PACHECO, José da. Tratado das execuções: execução fiscal. São Paulo: Saraiva, 1976. Comentários à lei de execução fiscal: Lei Federal no 6.830, de 22-09-1980. 9. ed. São Paulo: Saraiva, 2002.

THEODORO JUNIOR, Humberto. Curso de direito processual civil. 36. ed. Rio de Janeiro: Forense, 2001. v. 1

Curso de direito processual civil. 33. ed. Rio de Janeiro: Forense, 2002. v. 2.

VALDER DO NASCIMENTO, Carlos. Execução contra a fazenda pública: sua inversão no polo passivo em razão de erro material. Rio de Janeiro: Forense, 2000.

VILLAÇA AZEVEDO, Álvaro. Curso de direito civil: teoria geral das obrigações. 8. ed. São Paulo: Revista dos Tribunais, 2000.

ZAVASCKI, Teori Albino. Comentários ao Código de Processo Civil: do processo de execução, arts. 566 a 645. São Paulo: Revista dos Tribunais, 2000. v. 8. 
